\title{
Penggunaan SWOT Dalam Literasi Media (Penggunaan Media Digital Secara Positif Pada Generasi Milenial Di Madrasah Aliyah Yayasan Bina Cendikia Utama Kabupaten Cirebon)
}

\author{
Aan Mohamad Burhanudin \\ IAIN Syekh Nurjati Cirebon, \\ e-mail: aan.m.burhanudin@ syekhnurjati.ac.id
}

\begin{abstract}
ABSTRAK
Kegiatan pengabdian masyarakat ini bertujuan demi meningkatkan pemahaman tentang literasi media digital secara positif pada generasi milenial di Madrasah Aliyah Yayasan Bina Cendikia Utama Kabupaten Cirebon. Teknologi diciptakan untuk membantu, mempermudah dan memecahkan masalah manusia, maka pentingnya literasi media digital pada generasi milenial adalah untuk menggunakan media sesuai dengan kebutuhan, etika dan norma. Selain itu, literasi media dapat membentengi para generasi milenial dari penyalahgunaan media dari hal-hal negatif. Alat yang digunakan untuk menganalisis permasalahan ini adalah menggunakan Analisis SWOT seperti perencanaan strategi yang efektif dan efisien antara lain memaksimalkan potensi yang telah dimiliki, menyiapkan anggaran dana, menjalin kerjasama dengan media, dan meminimalisir faktor-faktor yang menjadi penghambat dalam pelaksanaan program. Penelitian ini adalah observasi lapangan dengan metode penelitian kualitatif.
\end{abstract}

Kata Kunci: Literasi Media, Generasi Milenial, Analisis SWOT

\begin{abstract}
The purpose of this community service is to increase the knowledge about media literacy on digital media positively for millennials at Madrasah Aliyah Yayasan Bina Cendikia Utama in Cirebon District. The technology was created to assist, facilitate, and to solve humanity's problems, so the significance of digital media literation, especially for millennials, is to how to use media inappropriate way. Furthermore, media literacy can be a weapon for millennials to guard them against the misapplication of media and other bad things. The analytical tools to solve the problem is by using SWOT Analysis like doing strategic planning, make a collaboration with media, and minimizing the threat factor. This research is observative research with qualitative research methods.
\end{abstract}

Keyword: Media Literacy, Millenial Generation, SWOT Analysis 


\section{PENDAHULUAN}

Literasi adalah sebuah topik hangat dan dinamis pada saat ini. Mulanya kemampuan literasi dinilai dalam kemampuan untuk menulis, membaca dan memberikan makna dalam sebuah teks (UNESCO, 2005). Awalnya, teks-teks media bisa didapatkan melalui media cetak dan media elektronik. Pesatnya perkembangan teknologi dan informasi yang terus berkembang dari hari ke hari, akan membawa dampak yang besar, sehingga kini perkembangan media digital menjadi massif dan menjangkau seluruh lapisan masyarakat. Akibatnya, konsep literasi konvensional juga berubah dan salah satunya adalah munculnya literasi digital.

Mereka-mereka yang lahir antara tahun 1980-1990 atau pada awal tahun 2000 dapat digolongkan menjadi generasi milenial. Penelitian yang dilakukan oleh Alvara Research Center pada 2018 menyebutkan bahwa generasi milenial adalah generasi yang memiliki predikat sebagai Digital Native. Individu-individu yang lahir setelah adanya adopsi teknologi digital secara besarbesaran inilah yang disebut Digital Native. Bukan berarti predikat ini dapat digeneralisasikan secara umum, namun anak-anak inilah yang familiar dengan dunia digital (www.techopedia.com). Internet menjadi sebuah hal yang tidak terpisahkan dalam kehidupan mereka dan menjadi kebutuhan primer.

Seperti yang dikemukakan oleh (Gilster, 1997), literasi digital mulai dikenal di awal tahun 1990. Ia menyatakan bahwa literasi digital adalah sebuah kemahiran dalam mencerna dan memanfaatkan informasi melalui bermacam-macam media digital yang memerlukan keselarasan dan keutuhan cara berpikir untuk menyikapi berbagai informasi yang diperoleh dari media-media digital.

Penelitian-penelitian pendahulu terkait literasi digital sudah banyak dilakukan. Pelatihanpelatihan terkait literasi sosial dapat meningkatkan kemampuan literasi digital secara positif. Hal tersebut dapat diidentifikasi mulai dari pemilihan sumber informasi, strategi pencarian informasi, keahlian dalam akses sumber informasi yang telah disesuaikan dengan kebutuhan, serta mengevaluasi hasil dari informasi yang telah didapatkan (Kurnianingsih, Rosini, \& Ismayati, 2017). Menurut (A'yuni, 2015) bahwa sosialiasi literasi digital penting agar para remaja mudah untuk mengidentifikasi dan mengevaluasi informasi yang tersebar di internet benar atau tidak. Para remaja juga harus punya kesadaran ketika mencari informasi dan memanfaatkan media sesuai kebutuhan masing-masing. Maka, mereka harus meningkatkan kemampuan kognitif dan teknis saat melakukan kegiatan pencarian informasi di internet supaya efektif dan efisien.

Di Indonesia, setiap 1 dari 3 penduduk adalah generasi milenial dan 8 dari 10 generasi milenial terhubung dengan internet. Maka perilaku yang sering ditunjukkan oleh generasi milenial adalah kecanduan internet. Mengapa banyak anak atau remaja yang kecanduan? Sebab gawai 
senantiasa menerikan respon ketika disentuh, sementara orang tua mengaktifkan "mode hening" ketika menghadapi anak. Bahaya tersembunyi lainnya yang ada dibalik penggunaan gawai maupun internet adalah adiksi terhadap game, penurunan daya konsentrasi, pornografi hingga kematian. Berikut rincian klasifikasi literasi digital dalam 26 poin;

Tabel 1. Klasifikasi literasi Digital

\begin{tabular}{llll}
\hline \multicolumn{1}{c}{ Alat dan Sistem } & Informasi dan Data & Berbagi dan Kreasi & $\begin{array}{c}\text { Sejarah \& Konteks } \\
\text { Kultural }\end{array}$ \\
\hline Dasar computer & Representasi & $\begin{array}{l}\text { Berpikir dengan } \\
\text { kreatif }\end{array}$ & $\begin{array}{l}\text { Kewargaan digital } \\
\text { Perangkat keras }\end{array}$ \\
$\begin{array}{l}\text { computer } \\
\text { Perangkat lunak dan } \\
\text { aplikasi }\end{array}$ & Perakitan & Dokumen & Perbedaan \\
Jaringan & Analisis dan & Multimedia & Hak intelektual \\
& penilaian & Komunikasi & Privasi dan identitas \\
Desain & Pengambilan & Pencitraan diri di & Agenda yang telah \\
& keputusan & dunia maya & dirancang \\
Pengayaan & Penyimpanan & Produktivitas & Dampak teknologi \\
& Navigasi & Berbagi dan & \\
\hline & kolaborasi & \\
\hline
\end{tabular}

Sumber: (Riel, 2012)

Secara singkat, komponen-komponen diatas menyatakan bahwa literasi digital tidak hanya berkutat dalam kemampuan menggunakan perangkat teknologi saja, namun harus bersamaan dengan adanya kemampuan untuk berinteraksi secara aktif dan positif serta dapat memaknai setiap pesan yang diperoleh dengan kritis sesuai dengan kebutuhan masing-masing individu.

Analisis SWOT adalah tools yang digunakan untuk mengenali faktor-faktor apa saja yang dapat mempengaruhi kelebihan dan kekurangan dalam sebuah organisasi, industry, produk, program, dan sebagainya. Hal-hal apa saja yang harus ditingkatkan dan ancaman apa saja yang harus ditanggulangi dalam pengelolaan yang berkelanjutan (Emet \& Tat, 2017). Penggunaan analisis SWOT untuk program pengabdian masyarakat dalam literasi media digital ini bermanfaat untuk menjadi acuan untuk mengambil keputusan yang strategis supaya target-target yang diinginkan dapat tercapai. 
Penulis melakukan pengabdian di Madrasah Aliyah Yayasan Bina Cendikia Kabupaten Cirebon karena para siswa yang bersekolah di tempat tersebut merupakan generasi milenial yang aktif menggunakan internet. Sehingga dirasa penting untuk melakukan pengabdian dengan mengusung tema literasi digital Berdasarkan latar belakang diatas, penulis tertarik melakukan penelitian dengan judul Penggunaan SWOT Dalam Literasi Media: Penggunaan Media Digital Secara Positif Pada Generasi Milenial di Madrasah Aliyah Yayasan Bina Cendikia Utama Kabupaten Cirebon.

\section{BAHAN DAN METODE}

Metode yang digunakan dalam program pengabdian kepada masyarakat ini adalah metode penelitian kualitatif. Penelitian kualitatif adalah sebuah prosedur penelitian yang digunakan untuk mengkaji gejala-gejala sosial di masyarakat secara menyeluruh berdasarkan data serta fakta melalui pengamatan dan dilaporkan secara holistik (Creswell, 2003).

Teknik yang digunakan untuk pengumpulan data adalah teknik observasi. Salah satu jenis observasi yang dikenal adalah observasi partisipan, yaitu peneliti juga menjadi anggota dalam objek penelitiannya (Kriyantono, 2009). Data-data yang dikumpulkan selama program pengabdian masyarakat berlangsung berupa dokumenta.si, wawancara dan kajian pustaka yang akan dikaitkan dengan analisis SWOT.

\section{HASIL DAN PEMBAHASAN}

\section{Strategi Literasi Media: Penggunaan Media Digital Secara Positif Pada Generasi Milenial di Madrasah Aliyah Bina Cendikia Kabupaten Cirebon}

Dahulu internet merupakan sebuah kemewahan yang hanya bisa diakses kelompok tertentu. Seiring dengan meningkatnya perkembangan teknologi informasi dan komunikasi yang didukung oleh keberadaan internet, maka transmisi informasi dari seluruh dunia dengan berbagai cara, isi dan klasifikasinya menjadi sangat banyak dan seolah-olah menembus dimensi ruang dan waktu. Hal ini menyebabkan terjadinya perubahan tingkah laku konsumen berita tersebut (Kurniasih \& Setiawan, 2017). Ditambah adanya generasi milenial yang menjadi user dari perkembangan teknologi informasi dan komunikasi.

Agar generasi-generasi milenial yang bersekolah di Madrasah Aliyah Bina Cendikia Kabupaten Cirebon ini tidak gagap dan salah dalam memanfaatkan teknologi informasi dan komunikasi, maka strategi literasi media yang dapat dilakukan untuk mewujudkan penggunaan media digital secara positif adalah dengan pemberian materi tentang jenis-jenis media, seperti media cetak, media elektronik dan media digital serta memahami tujuan penggunaannya; dan 
pemberian materi tentang pengelolaan informasi berbentuk visual dan audiovisual sesuai kode etik dan norma. Kegiatan ini dilangsungkan pada bulan Agustus 2019.

1. Dinamika generasi milenial dalam menggunakan media literasi di era digital

Dalam kehidupan sehari-hari, generasi milenial akrab menggunakan teknologi dan terhubung dengan internet. Hal ini menunjukkan bahwa internet telah menjadi kebutuhan pokok dalam hidupnya. Karena itu perilaku yang paling melekat dalam diri generasi milenial kita adalah kecanduan internet. Hal ini dikarenakan internet menawarkan kemudahan dalam hidup mereka, semua bisa diakses dari gawai mereka, sehingga apabila sebentar saja terputus dari internet maka timbul rasa ketidaknyamanan dalam hidupnya.

Teknologi diciptakan untuk membantu dan mempermudah memecahkan masalah dalam kehidupan manusia. Perangkat media dan teknologi pengiriman pesan secara konvensional mulai ditinggalkan karena memiliki banyak faktor keterbatasan. Tuntutan aktivitas dan kebutuhan yang serba cepat menyebabkan perangkat konvensional tidak lagi mampu mengikuti perkembangan zaman dan tidak lagi diminati. Dulu proses transmisi pesan memerlukan waktu yang sangat lama dan memerlukan banyak tahap hingga akhirnya pesan tersebut dapat dikirimkan dan sampai di tujuan, misalnya menggunakan surat, telepon umum dan sebagainya. Kini akibat terkoneksinya perangkat teknologi dengan internet, maka perubahan-perubahan itu dapat kita rasakan dampaknya secara langsung. Manfaat dari literasi informasi digital antara lain, sebagai sarana komunikasi, e-learning, meningkatkan kreativitas, sumber informasi, jejaring sosial dan mendukung industri atau usaha skala kecil (Muna, 2019).

Jika literasi media digital sudah sangat cepat dan canggih, maka harus didukung dengan masyarakat atau pengguna yang sadar dan bertanggung jawab ketika menggunakan internet. Ketika mengakses internet, para pengguna harus memiliki dasar-dasar literasi digital yaitu mampu mengoperasikan perangkat digital, mampu mengelola informasi sesuai kebutuhan, mampu menerapkan informasi yang diperoleh dengan positif dan bertanggung jawab (Muna, 2019).

Kemudahan-kemudahan yang ditawarkan teknologi ini seperti dua sisi masa uang. Di satu sisi kita terbuai dengan efektifitas dan efisiensi saat menggunakan teknologi, namun juga banyak bahaya-bahaya yang mengintai dibaliknya. Sebagai pengguna internet haruslah kritis dalam menyikapi berbagai informasi yang tersebar di intermet. Pilihlah media-media yang kredibel dan terpercaya agar informasi-informasi yang akan kita peroleh bersifat valid dan dapat dipertanggungjawabkan kebenarannya.

American Academy of Pediatrics (2016) menyebutkan bahwa remaja usia 13-19 tahun sebaiknya tidak lebih > 2 jam / hari saat mengakses internet dan perlu bimbingan dari orang tua. Mengapa bisa demikian? Seringkali para remaja memilih informasi yang tidak sesuai dengan 
klasifikasinya, maka disinilah peran penting dari orang tua untuk membimbing dan mengarahkan anak-anak mereka. Selain itu, jika para remaja dibiarkan tanpa pengawasan saat menggunakan internet, ada bahaya lain yang seringkali tidak disadari oleh mereka seperti kecanduan, menurunnya tingkat konsentrasi, pornografi hingga kematian.

2. Materi tentang pengelolaan informasi media digital serta memahami tujuan penggunaannya sesuai kode etik dan norma

Saat kita membutuhkan informasi maka hal yang pertama kita tuju adalah membuka media, baik media cetak, media elektronik atau internet. Generasi milenial yang hidup ditengah arus modernisasi yang serba cepat dan praktis seringkali menggunakan internet yang terhubung ke gawai masing-masing. Kini dunia ada di dalam genggaman, konsep ruang dan waktu seakan nihil dengan adanya teknologi informasi dan komunikasi. Para generasi milenial ini perlu dikenalkan kepada bentuk-bentuk media lain selain menggunakan gawainya.

Setelah mereka mampu memahami tujuan penggunaan dari masing-masing jenis media tersebut, maka langkah selanjutnya adalah mengetahui motif apa yang ingin mereka cari sesuai dengan media yang digunakan.

a. Motif mencari uang: Kini mencari uang tidak hanya bisa dilakukan di dunia nyata saja, namun pekerjaan di dunia maya makin banyak peminatnya. Muncul lapangan pekerjaan baru yang memanfaatkan jejaring internet. Berbekal dengan kreativitas maka siapa saja baik individu, kelompok, produk maupun perusahaan kini bisa menjadi sumber berita atau yang sering disebut influencer. Media digital dianggap menjadi sarana promosional yang efektif dan efisien sehingga dapat mengeruk pundi-pundi rupiah dengan jumlah besar dan dalam waktu singkat jika dibandingkan dengan pekerjaan konvensional. Hal-hal inilah yang seringkali membuat para generasi milenial tergiur dengan konsep sukses secara instan.

Ada juga pelaku-pelaku di dunia digital yang bekerja dengan mempromosikan usaha dari orang lain atau disebut buzzer. Mereka memiliki follower base yang kuat dan berjumlah banyak sehingga mampu menggiring opini terhadap suatu hal atau kejadian tertentu. Tentu saja hal tersebut seringkali membawa dampak negatif misalnya menyebarkan hoax, menciptakan kondisi yang tidak nyaman, saling menjelekkan lawan, dan sebagainya.

b. Motif mencari perhatian: Ketika pengguna media digital ini berjejaring, maka mereka terhubung dengan banyak orang lainnya baik yang mereka kenal bahkan yang mereka tidak kenal secara tidak sengaja. Manusia seringkali memiliki rasa untuk diperhatikan tingkah lakunya. Media digital memiliki kemampuan lebih yang tidak dimiliki oleh media ccetak 
maupun elektronik, yaitu kemampuan untuk mengontrol informasi yang bersifat pribadi secara real time.

Para pengguna media digital ini memiliki control untuk mengatur informasi apa saja yang akan disebarkannya. Biasanya mereka akan mengunggah foto atau apapun yang mencerminkan kejadian yang dialaminya dengan harapan akan dilihat dan direspon orang lain. Sehingga jumlah komentar dan likes menjadi standar baru dalam berinteraksi di media digital khusunya media sosial.

c. Motif mencari kesibukan: Mereka menggunakan media sosial sebagai sarana untuk refreshing. Biasanya mereka ini jarang untuk membagikan informasi di media sosial dan lebih senang mengamati saja.

d. Motif mencari kepuasan batin: Mereka ini seringkali mengekspresikan dirinya di media sosial karena alasan-alasan tertentu. Biasanya mereka sering menulis curahan isi hatinya untuk melampiaskan emosinya. Maka jangan kaget ketika sedang berselanacar di dunia maya menemukan opini, keluh kesah, luapan emosi yang tidak dapat dituangkan di dunia nyata.

e. Motif mencari hiburan: Para user dengan motif ini biasanya suka membagikan hal-hal yang lucu, gembira, menyenangkan baik dari pengalaman pribadi maupun dari sumber lain. Mereka juga tidak suka dengan diskusi yang bersifat sensitive karena tidak sesuai dengan motif utama mereka yaitu bersenang-senang dan mencari hiburan.

f. Motif mencari teman dan jodoh: Ketika kita berada di dunia maya, maka secara langsung maupun tidak langsung kita akan terhubung dengan seluruh pengguna media sosial itu. Maka mereka ini suka memanfaatkan jejaring pertemanan itu untuk memperluas koneksi, menjalin silaturahmi, menambah teman hingga mencari jodoh. Namun sayangnya, banyak kejadian buruk yang berawal dari pertemanan itu misalnya penipuan, kekerasan, penculikan hingga pembunuhan. Maka generasi milenial ini perlu dibekali dengan pengetahuan untuk menjaga diri, privasi dan informasi pribadi mereka.

g. Motif galau: Dari sekian informasi yang berlalu lalang di dunia maya, berbagai macam orang dengan motifnya sendiri dan berbagai macam media sosial yang digunakan, masih ada saja yang bingung dengan motifnya sendiri. Tidak jarang mereka tidak mendapatkan manfaat atau tidak menemukan apa yang mereka cari sehingga hanya berpindah-pindah dari satu akun ke akun lainnya.

Dunia digital seperti dua sisi masa uang, tidak hanya konten-konten yang bermuatan positif yang beredar, namun ada juga konten-konten yang bersifat negatif yang mudah didapatkan. Para generasi milenial yang umumnya sedang dalam proses mencari jati diri inilah yang harus dibekali 
dengan pengetahuan literasi media digital dengan positif agar mereka dapat mengaktualisasikan dirinya di jalan yang benar. Serta membentengi diri mereka dari serangan berita-berita hoax.

Banyak kejadian-kejadian yang menjadi viral ketika terekspos di media sosial. Maka selain dibekali dengan kompetensi memaknai isi berita diatas, generasi milenial ini juga dilatih untuk membuat konten-konten yang menarik, positif dan bermanfaat karena viral saja tidak cukup. Untuk dapat merealisasikan hal tersebut maka diperlukan strategi-strategi dalam membuat konten, yaitu:

1) Jauhi konten atau berita hoax

2) Konten harus sesuai dan menjangkau segmentasi khalayak yang dituju

3) Informasi yang diberikan menarik, memiliki unsur kebaruan dan sarat akan informasi

4) Proses pembuatan konsep hingga penyajian konten dikemas dengan cara-cara yang kreatif dan enak dilihat

5) Publikasi konten yang ramah berbagi. Maksudnya adalah jangan lupa menambahkan tombol share ke media sosial lain sehingga ketika ada audience yang menyukai konten yang telah kita buat maka ia akan langsung menyebarkan di media sosialnya dan akan dilihat lagi oleh banyak orang

\section{Analisis SWOT dalam Literasi Media Penggunaan Media Digital Secara Positif Pada Generasi Milenial di Madrasah Aliyah Bina Cendikia Kabupaten Cirebon}

Dalam program pengabdian masyarakat yang bertema Literasi Media: Penggunaan Media Digital Secara Positif Pada Generasi Milenial di Madrasah Aliyah Bina Cendikia Kabupaten Cirebon ini, perlu adanya perencanaan strategis dengan menggunakan analisis SWOT. Mengapa hal ini diperlukan? Karena jika dapat memahami faktor-faktor baik dari internal maupun eksternal yang mendukung atau justru menghambat pelaksanaan kegiatan, maka kita akan dapat membuat perencanaan yang efektif dan efisien. 
Tabel 1. Matriks SWOT

\begin{tabular}{|c|c|c|}
\hline Internal & $\begin{array}{l}\text { Peluang (Opportunity) } \\
\text { 1) Berkontribusi dalam } \\
\text { kegiatan literasi media } \\
\text { di Kabupaten Cirebon } \\
\text { 2) Menjadi pilot project } \\
\text { kegiatan serupa di } \\
\text { sekolah lain di sekitar } \\
\text { Kabupaten Cirebon }\end{array}$ & $\begin{array}{l}\text { Ancaman (Threat) } \\
\text { 3) Memerlukan anggaran } \\
\text { lebih untuk menunjang } \\
\text { program } \\
\text { 4) Menyebabkan kegiatan } \\
\text { program kerja lain } \\
\text { kurang mendapat } \\
\text { perhatian }\end{array}$ \\
\hline $\begin{array}{l}\text { Kekuatan (Strength) } \\
\text { 5) Sumber daya manusia } \\
\text { yang tersedia } \\
\text { 6) Adanya mentor-mentor } \\
\text { yang berpengalaman dan } \\
\text { berkualitas } \\
\text { 7) Materi pembelajaran } \\
\text { yang sustainable dan } \\
\text { mengikuti } \\
\text { perkembangan zaman } \\
\text { 8) Materi yang menarik dan } \\
\text { dapat diaplikasikan } \\
\text { dalam kehidupan sehari- } \\
\text { hari }\end{array}$ & $\begin{array}{l}\text { Rencana Strategis (SO) } \\
\text { Membangun jejaring dengan } \\
\text { media lokal untuk } \\
\text { memberikan pelatihan } \\
\text { Membuka kerjasama dengan } \\
\text { media lokal dan institusi } \\
\text { pendidikan lain untuk } \\
\text { kegiatan praktek kerja } \\
\text { lapangan }\end{array}$ & $\begin{array}{l}\text { Rencana Strategis (ST) } \\
\text { Memanfaatkan potensi yang } \\
\text { dimiliki untuk menghadapi } \\
\text { perkembangan teknologi } \\
\text { informasi }\end{array}$ \\
\hline $\begin{array}{l}\text { Kelemahan (Weakness) } \\
\text { 9) Kurangnya pengetahuan } \\
\text { para siswa tentang } \\
\text { literasi media } \\
\text { 10) Kurangnya sarana dan } \\
\text { prasarana } \\
\text { 11) Kurangnya kuantitas } \\
\text { kegiatan serupa }\end{array}$ & $\begin{array}{l}\text { Rencana Strategis (WO) } \\
\text { Merancang anggaran khusus } \\
\text { untuk kegiatan } \\
\text { Meminta arahan dari } \\
\text { kalangan akademisi dan } \\
\text { professional } \\
\text { Membuat rangkaian acara } \\
\text { yang menarik dan sesuai } \\
\text { dengan perkembangan } \\
\text { zaman }\end{array}$ & $\begin{array}{l}\text { Rencana Strategis (WT) } \\
\text { Meminimalisir faktor-faktor } \\
\text { yang menjadi kelemahan } \\
\text { demi meningkatkan kualitas } \\
\text { dan kuantitas program } \\
\text { literasi media }\end{array}$ \\
\hline
\end{tabular}

Sumber: Data Primer, 2019 


\section{KESIMPULAN DAN SARAN}

Kesimpulan yang dapat ditarik dari pembahasan diatas adalah bahwa perkembangan teknologi informasi dan komunikasi yang dinamis harus diimbangi dengan kualitas sumber daya manusia yang baik. Literasi digital sudah menjadi kebutuhan primer manusia, maka perlu langkahlangkah yang terpadu dalam memenuhi kebutuhan tersebut. Para generasi milenial dituntut untuk melek teknologi agar memiliki kecerdasan dalam menggunakan media digital demi terciptanya masa depan Indonesia yang maju dan berdaya saing. Materi-materi yang menarik untuk dibahas dan tidak akan lekang oleh waktu karena selama manusia masih ada untuk berinteraksi dan teknologi yang selalu berkembang mengikuti zaman

\section{UCAPAN TERIMA KASIH}

Terima kasih banyak penulis sampaikan kepada Ketua, Guru-guru dan generasi millenial Madrasah Aliyah Yayasan Bina Cendikia Utama Kabupaten Cirebon, yang telah sangat berkontribusi dalam penyelesaian kegiatan pengabdian ini.

\section{DAFTAR PUSTAKA}

A’yuni, Q. Q. (2015). Literasi Digital Remaja Di Kota Surabaya. Journal Unair. Retrieved from http://journal.unair.ac.id/download-fullpapers-ln53e61a7e60full.pdf

Creswell, J. W. (2003). Research Design: Qualitative, Quantitative, and Method Approached. California: Sage Publication, Inc.

Emet, G., \& Tat, M. (2017). SWOT ANALYSIS: A Theoretical Review. The Journal of International Sociial Research, 10(51). Retrieved from http://www.sosyalarastirmalar.com/ cilt10/sayi51_pdf/6iksisat_kamu_isletme/gurel_emet.pdf

Gilster. (1997). Digital Literacy. New York: Wiley.

Kriyantono, R. (2009). Teknik Praktis Riset Komunikasi. Jakarta: Kencana Prenada Media Group. Kurnianingsih, I., Rosini, \& Ismayati, N. (2017). Upaya Peningkatan Kemampuan Literasi Digital Bagi Tenaga Perpustakaan Sekolah dan Guru di Wilayah Jakarta Pusat Melalui Pelatihan Literasi Informasi. Jurnal Pengabdian Kepada Masyarakat, 3(1). Retrieved from https://jurnal.ugm.ac.id/jpkm/article/view/25370

Kurniasih, Y. P., \& Setiawan, M. V. (2017). Analisis Peran Perpustkaan Universitas Brawijaya dalam Mewujudkan Gerakan Literasi Informasi Digital. Perpustakaan Universitas Brawijaya. Malang.

Muna, N. R. (2019). Dinamika Generasi Milenial Dalam Menggunakan Media Literasi Di Era Digital. 
Riel, J. (2012). Charting Digital Literacy: A Framework For Informastion Technology And Digital Skills In The Community College. SSRN Electronic Journal. Retrieved from https://www.researchgate.net/publication/282861959

UNESCO. (2005). Education for All : Literacy for Life. In UNESCO Education and Literacy. 